\title{
Guidelines for the retrofit of the school building stock for sustainable urban regeneration of the city of Rome
}

\author{
C. Calice, C. Clemente, L. de Santoli \& F. Fraticelli \\ Department CITERA, University of Rome, Italy
}

\begin{abstract}
The City of Rome is trying to come into line, culturally and strategically, with European standards of environmental health and energy savings. This study is designed as a roadmap for the retrofit of existing building stock, through the analysis of case studies of major significance in terms of building characteristics and period of construction. The recognition of the consistency of the existing school building stock and the subsequent selection of the buildings that are representative of general conditions allowed us to compare results and draw from them intervention guidelines that are applicable to almost all of the school building stock. The guidelines developed by the authors take into account the optimisation of the building envelope and plant system, as well as the pay-back period of each case. The interventions, with their low investment costs, have significant benefits in terms of energy efficiency, with a subsequent reduction in greenhouse gas emissions, and in terms of indoor and outdoor environmental quality, and propose a systemic approach to the retrofit of Mediterranean cities, which often have ancient and monumental historic centres that need to be protected and enhanced, as well as in the established suburbs, defined as those that appeared up to the 1970s-1980s. For these buildings, characterised by great potential for transformation and often with poor architectural and technological quality, the energy retrofit is also an opportunity to redesign and redefine the levels-objectives of indoor comfort. The reduction of energy consumption in school buildings, estimated at about $40 \%$ for the envelope and $20 \%$ for the plant, other than the evident environmental benefits to the territory, also has a significant impact on the education of the individual awareness of the users. Widespread retrofit of public structures at the disposal of young students, other than having a powerful impact in the reduction of greenhouse gases, constitutes a
\end{abstract}


fundamental element in education on environmental issues and quality of the built, creating an unquantifiable extra value for sustainable development in the City of Rome and for the construction of more liveable and civilised cities.

Keywords: retrofit, roadmap, school building, environment, energy saving, plants, envelopes.

\section{Introduction}

According to the World Energy Outlook 2011 [1], despite the unfavourable economic situation, the demand for energy globally from 2011 to 2035 is forecast to increase by about one-third and necessitates a radical change of direction in the energy management of the existing building stock towards sustainable energy strategies in management and retrofitting [2].

This study puts itself forward as a methodological approach to the widespread problems of saving energy, in which the construction sector is a fundamental element.

The school building stock in particular is suffering from serious structural problems, complicated by the lack of an integrated policy for the management and maintenance of buildings and plant; the educational building stock of the City of Rome in terms of its quantity and quality, in its variety of case studies and types, is fertile ground for research into the development of an interventional model that would be valid at a national level.

The example of schools can be a very important tool for the spread of certain procedures for construction and upgrading, both for the capillary distribution throughout the territory of school buildings of all types and levels, as well as for the enhancement of the centrality of the wellbeing of the end users, for the diffusion of eco-friendly materials and, above all, for the ensuring the establishment culturally of a new attitude towards energy consumption and the widespread and indispensable use of renewable energy.

In the territory of Rome there are 1,394 buildings destined for school use, and of these 1,296 are municipal property, while 104 belong to the Province of Rome.

Rome is currently in $26^{\text {th }}$ place in the ranking of Italian cities involved in upgrading and making schools safe; $52.82 \%$ of the schools were built prior to 1974 and in 2009 only $58.64 \%$ of them have a certificate of fitness for use [3].

Of school buildings owned by the City, the last reference for the evaluation of their numbers and articulation is an inventory of municipal assets as of June 30, 2000; according to that, the buildings recorded as being actually used for the sole purpose of education are 1,296, of which 158 are nurseries. This data allows an assessment of the numbers and effective use of buildings.

These brief guidelines on the size of the municipal educational building stock also allow us to make preliminary assessments about the quality of the construction of the buildings and their energy performance [4].

The buildings constructed between the 1950s and 1980s, from the studies and surveys conducted, present with performance characteristics in terms of thermal and acoustic isolation that are absolutely not in line with the current 
requirements of environmental comfort and energy management; in very many cases, they are in a state of profound degradation, mainly concentrated in the system of vertical closures (outside walls and windows and doors) and of coverings.

This family of buildings represents the largest percentage of buildings currently in use, since the ' 80 s represented the peak historical period for building $\left(600,000 \mathrm{~m}^{3} /\right.$ year in $1981,400,000 \mathrm{~m}^{3} /$ year in 1983-1984); the buildings from this period were built immediately after the publication of the provisions of the Ministerial Decree of 18 December 1975 [5], which has been the standard normative reference for the construction of new schools from the 70 s up to today. This homogeneity of the sample is useful in identifying the distributive, constructive, dimensional and planimetric analogies of a very substantial set of buildings.

Pre-World War II buildings, present in the historic town centre and longestablished city, are often characterised by their large cubature and very large service and connective areas, which, like their surfaces, require a lot more energy to be kept at required levels. In some cases, insertion into the fabric of the Historic Centre also involves a large consumption of resources to ensure the adequate lighting of interior spaces. Despite these shortcomings, the overall integrity of these buildings and the good state of maintenance of their closure systems, built with massive pre-modern technologies, in addition to better thermal performance in the outer opaque walls, lessens the problem of their energy management and their eventual redevelopment $[6,7]$.

From the point of view of "reconverting" and enhancing this large building stock in energy terms, also in the light of the avowed centrality and urgency of the issue of modernisation and rationalisation of the stock of school buildings nationwide, it is opportune to undertake effective strategies and follow guidelines for intervention that are useful in optimising the available economic resources and maximising the achievable results $[8-10]$.

\section{Method}

\subsection{Choice of the pilot projects}

The City of Rome is divided into 19 municipalities, each with its own administration and management. The Historic Centre, I, and Municipalities V and VIII are those with the highest concentration of volume and energy consumption. They were chosen therefore, in order to conduct an analysis of substantial statistical significance of the samples, for their representative dimensional cubature, for their constructive characteristics and for the chronological distribution of their construction. An operation carried out on building complexes with similar characteristics allows us to direct a large part of the interventions on the entire stock, focusing immediately on the causes of the problems of degradation and inefficiency and the most effective lines of action to take. 
The buildings chosen are representative of the types common in the Historic Centre and the construction types and practices that are widespread in the established fabric of outlying districts.

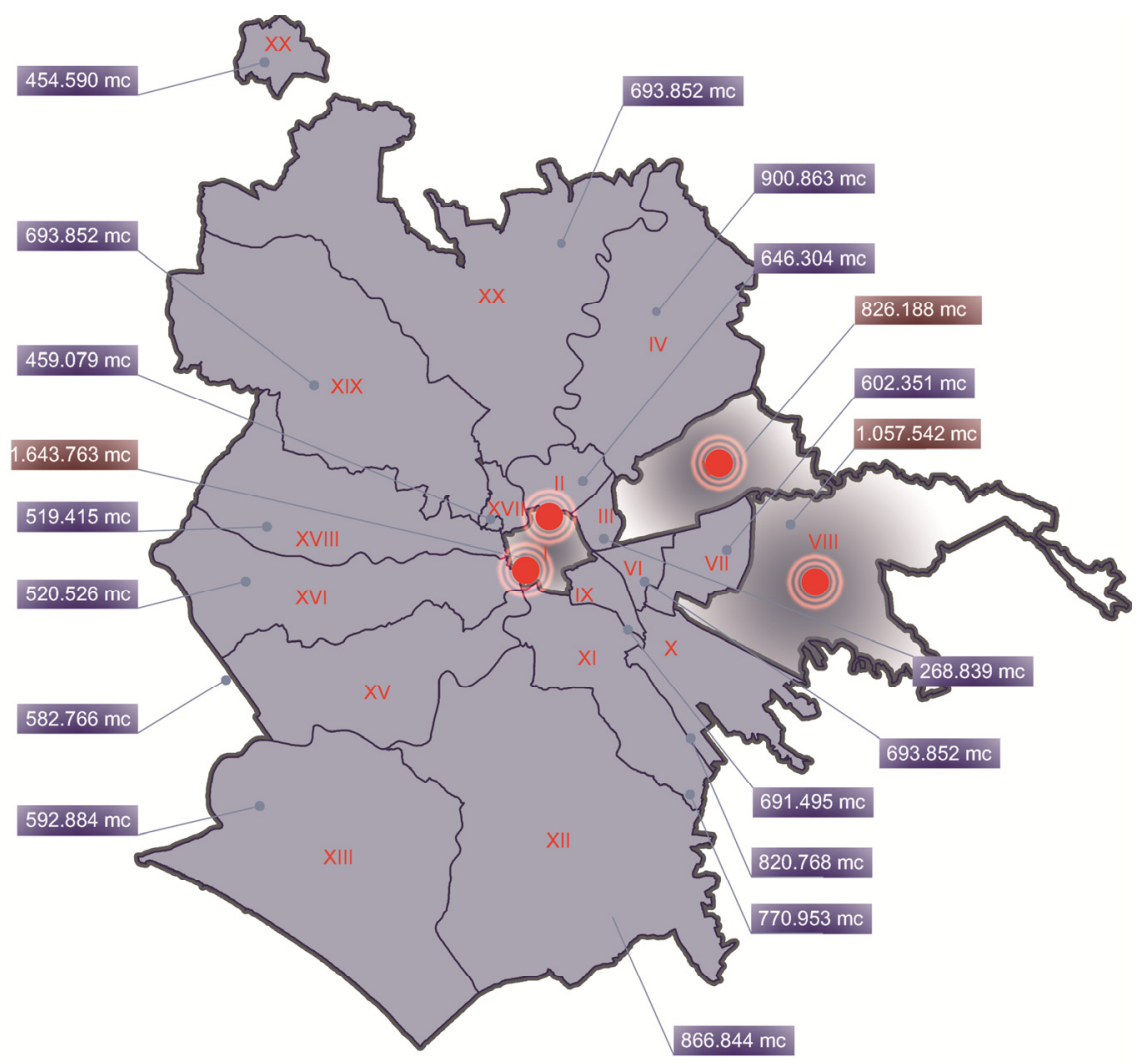

Figure 1: Geographical distribution of school building stock.

The first two projects - the "Regina Margherita" Nursery and Primary School and the "Elsa Morante" Comprehensive Institute Nursery, Primary and Grade 1 Secondary School in the Historic Centre, are valid for their characteristics in terms of dimensions, technology and architectural value which are shared by about $68 \%$ of the school buildings of the I Municipality and Historic Centre; similarly, the projects in the suburbs - the Comprehensive Institute of Nursery, Primary and Grade 1 Secondary School in Via dell'Archeologia and the "Angelica Balabanoff " Middle School - were chosen because they were built in the ' 80 s, belonging therefore to the sample from the historic peak of the construction of school buildings in the metropolitan area, which, in terms of number of buildings, constitute about $60 \%$ of the city's school building stock. 


\subsection{The phases of the study}

The strategic study is divided into 4 phases:

1. Preliminary phase of surveying initial data, identification of sites for pilot projects.

2. Phase of analysis of the current state of affairs, definition of pilot projects.

3. Phase of selection and analysis of integrated redevelopment interventions.

4. Phase of synthesis and delineation of guidelines.

\section{The study}

The investigation led to the identification of the dimensional characteristics of the buildings, information on electrical and heat consumption over the previous three years, inspections for the examination and direct verification of data, as well as the preparation of a detailed survey and thermographic and thermophysical surveys useful for the characterisation of the building envelope in terms of thermal performance.
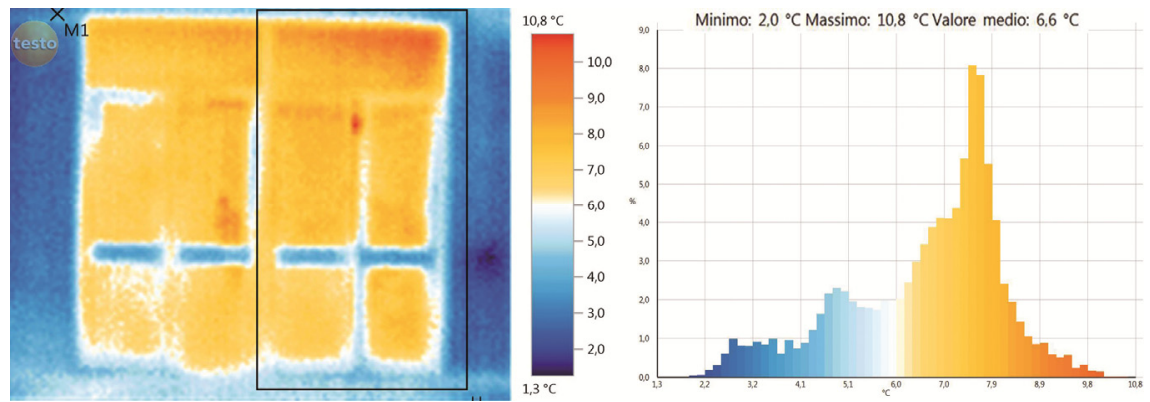

Figure 2: Thermographic surveys on windowed components.

For the analysis of the four case studies the following software was used in calculations: Software TFM estimate 10_6.1, Autodesk Ecotect Analysis 2010, Physibel Software for analysis of thermal bridges and thermal analysis of the finite elements in line with EN ISO 10211-2, Dartwin Frame simulator, Dartwin Brick simulator.

The determination of the thermal energy demand of the building for airconditioning in summer and winter led to the formulation of an overall judgment on the energy performance with reference to the legislation in force (Legislative Decree 211/2006 ad s.m.i.), and the assessment of the impact of the building envelope on energy requirements and the adequacy of the existing plant.

Here below are the values obtained for EPCI (index of seasonal demand for primary energy):

Historic Centre: current EPCI equivalent to $14 \mathrm{kWh} / \mathrm{m}^{3}$ per year.

Established city: current EPCI equivalent to $18-24 \mathrm{kWh} / \mathrm{m}^{3}$ per year. 
Thermal analyis of current situation

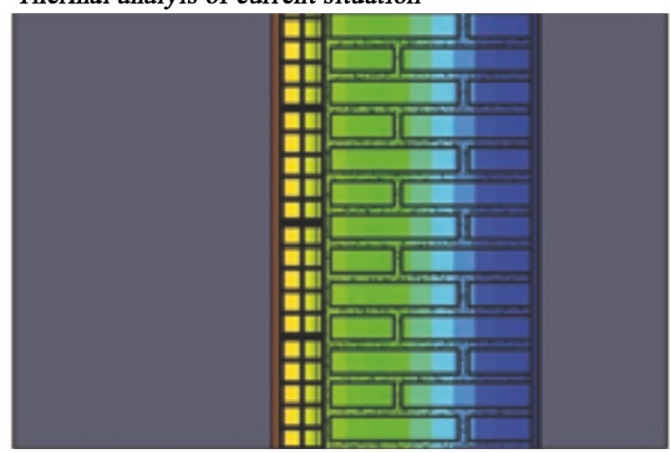

Thermal analyis of post-operam situation

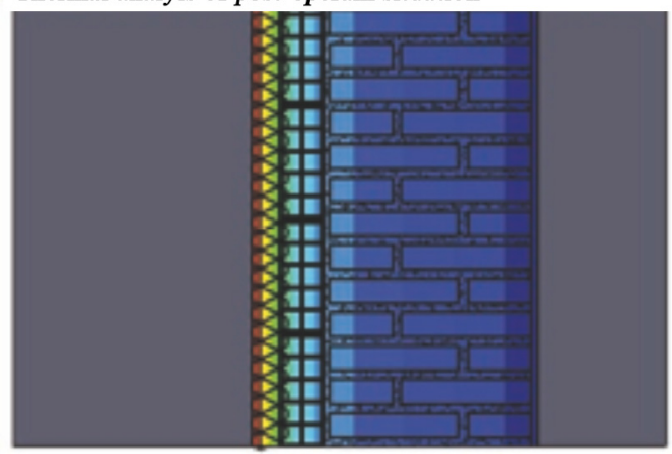

Figure 3: Thermal analysis on external wall.

\section{The definition of intervention}

On the basis of the above-described analytical framework, interventions were hypothesised on the building-plant system in relation to its receptivity to the transformation of the same and to energy and economic opportunities.

The interventions on the envelope regard vertical opaque structures, external window and door frames and shielding and shading systems, roof and floor systems, provided that these components bound the heated volume to the outside and to unheated spaces.

Interventions on the plant, instead, evaluated individually and in relation to those on the envelope, essentially concern: the replacement of the equipment for the production and control of heat with the introduction of condensing boilers of suitable dimensions according to the peak power required for the containment of costs and the improvement of production efficiency; optimisation of the heating of spaces through the widespread use of thermal valves, in particular in environments that have very irregular cycles of use (valves and thermostatic probes, assisted management of ventilation and replacement air) to improve the conditions of indoor comfort as well; a feasibility study on the use of solar 


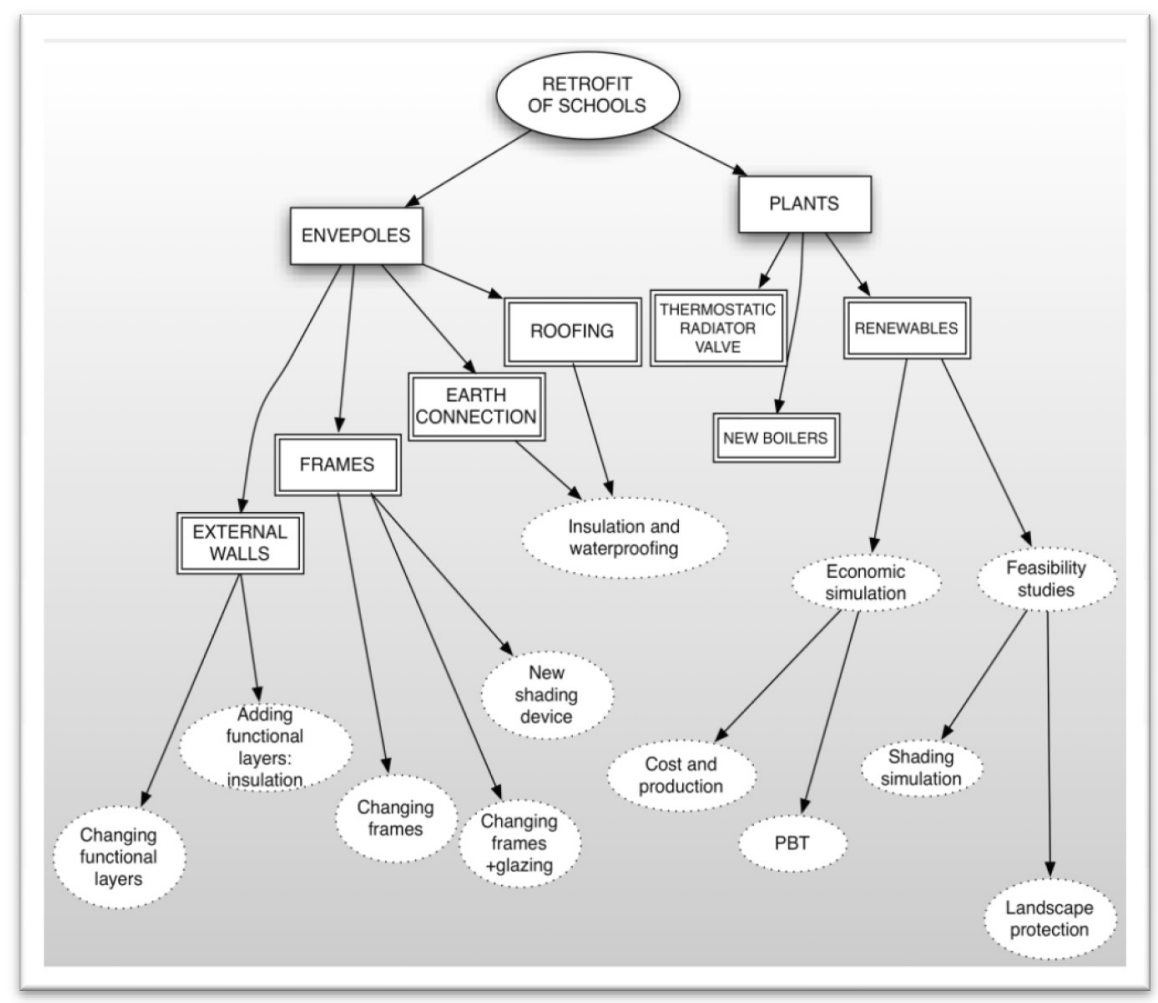

Figure 4: $\quad$ Smart map of intervention.

thermal systems and the adoption of innovative technological or management systems (solar and photovoltaic panels) $[11,12]$.

\section{Discussion on results and guidelines}

The organisation of the investigations carried out and the results obtained allow the direction of subsequent interventions aimed at improvement, on the basis of an overview, which is relevant with regard to a precise and decontextualised approach to energy issues in the building-plant system; this systematic approach optimised on the specificity of school buildings and their functional and management characteristics, through the definition of guidelines, output and final performance objectives to be achieved, allows the definition of a new operative standard for planning and preliminary evaluation of building renovation projects associated with energy retrofit, codifying the parameters to evaluate projects in development and already underway. 
Table 1: $\quad$ Brief comparison of ante-operam results.

\begin{tabular}{|c|c|c|c|c|}
\hline & $\begin{array}{c}\text { Case 1: } \\
\text { Historic } \\
\text { Centre }\end{array}$ & $\begin{array}{c}\text { Case 2: } \\
\text { Historic } \\
\text { Centre }\end{array}$ & $\begin{array}{c}\text { Case 3: } \\
\text { Historic } \\
\text { Centre }\end{array}$ & $\begin{array}{c}\text { Case 4: } \\
\text { Historic } \\
\text { Centre }\end{array}$ \\
\hline Current EPCI [kWh/m3 year] & 14,6 & 14,1 & 24,1 & 18,5 \\
\hline Incidence of external vertical walls & $42,30 \%$ & $43,30 \%$ & $21,80 \%$ & $25,10 \%$ \\
\hline Incidence of external doors/windows & $37,50 \%$ & $37,30 \%$ & $33,30 \%$ & $37,00 \%$ \\
\hline incidence of covers & $13,60 \%$ & $15,80 \%$ & $26,40 \%$ & $29,20 \%$ \\
\hline Oversize of plant & $384,40 \%$ & $211,80 \%$ & $165,51 \%$ & $120,00 \%$ \\
\hline
\end{tabular}

Table 2: $\quad$ Summary charts.

\begin{tabular}{|c|c|c|c|c|c|c|c|c|c|c|}
\hline & INTERVENTION & $\begin{array}{c}\text { Envelope } \\
\text { requirements } \\
\text { [KWh] }\end{array}$ & $\left.\begin{array}{c}\mathrm{Qh} \\
{[\mathrm{KWh} / \mathrm{mc}]}\end{array}\right]$ & $\begin{array}{c}Q \\
\text { [KWh/anno] }\end{array}$ & $\begin{array}{c}\text { Epci } \\
\text { [kwh/m3 } \\
\text { anno| }\end{array}$ & $\begin{array}{c}\text { GLOBAL } \\
\text { EFFICIE } \\
\text { NCY }\end{array}$ & $\eta e$ & $\eta \mathrm{r}$ & १d & $\eta$ \\
\hline & CURRENT SITUATION & $273.102,50$ & 12,52 & $454.831,39$ & 14,60 & 62,2 & 96,0 & 73,7 & 97,0 & 87,7 \\
\hline & CLADDING AND INSULATING PLASTER & $216.213,06$ & 9,91 & $378.549,44$ & 12,10 & 59,5 & 96,0 & 70,9 & 97,0 & 86,5 \\
\hline & ROOF INSULATION & $238.890,56$ & 10,95 & $410.606,94$ & 13,20 & 60,5 & 96,0 & 71,9 & 97,0 & 87,3 \\
\hline 늠 & NEW FRAMES & $235.064,44$ & 10,78 & $405.220,28$ & 13,00 & 60,3 & 96,0 & 71,4 & 97,0 & 87,3 \\
\hline 压 & INSULATED ENVELOPE & $149.685,00$ & 6,86 & $281.668,61$ & 9,00 & 56,2 & 96,0 & 67,6 & 97,0 & 84,8 \\
\hline & NEW PLANTS & $273.102,50$ & 12,52 & $315.950,83$ & 10,10 & 86,5 & 96,0 & 98,0 & 97,0 & 94,8 \\
\hline & TOTAL RETROFIT & $149.685,00$ & 6,86 & $175.475,83$ & 5,60 & 85,7 & 96,0 & 97,0 & 97,0 & 94,8 \\
\hline & CURRENT SITUATION & $278.672,78$ & 12,18 & $460.873,89$ & 14,10 & 62,2 & 96,0 & 73,7 & 97,0 & 87,4 \\
\hline سّن & CLADDING AND INSULATING PLASTER & $171.631,11$ & 7,50 & $317.191,67$ & 9,70 & 56,3 & 96,0 & 66,5 & 97,0 & 86,0 \\
\hline$\frac{2}{8}$ & ROOF INSULATION & $221.324,17$ & 9,68 & $384.648,89$ & 11,80 & 59,5 & 96,0 & 70,4 & 97,0 & 86,8 \\
\hline & NEW FRAMES & $230.879,17$ & 10,09 & $389.771,11$ & 11,90 & 61,2 & 96,0 & 72,1 & 97,0 & 86,9 \\
\hline$\sum_{4}$ & INSULATED ENVELOPE & $74,405,56$ & 3,41 & $155.058,61$ & 6,50 & 51,1 & 96,0 & 62,8 & 97,0 & 82,8 \\
\hline yै & NEW PLANTS & $273.102,50$ & 11,94 & $322.650,00$ & 9,90 & 86,1 & 96,0 & 97,0 & 97,0 & 95,3 \\
\hline & TOTAL RETROFIT & $74,405,56$ & 3,41 & $83.667,78$ & 2,70 & 89,5 & 96,0 & 97,0 & 97,0 & 99,1 \\
\hline$\Sigma_{4}$ & CURRENT SITUATION & $409.667,50$ & 17,91 & $721.391,11$ & 24,10 & 59,2 & 96,0 & 74,3 & 98,0 & 81,9 \\
\hline & CLADDING AND INSULATING PLASTER & $323.585,28$ & 14,15 & $609.509,17$ & 20,30 & 55,8 & 96,0 & 70,9 & 98,0 & 80,4 \\
\hline & ROOF INSULATION & $254.593,61$ & 11,13 & $517.290,28$ & 17,30 & 52,1 & 96,0 & 67,7 & 98,0 & 78,7 \\
\hline & INSULATED FLOOR & $383.183,89$ & 16,75 & $683.936,67$ & 22,80 & 58,3 & 96,0 & 73,8 & 98,0 & 80,9 \\
\hline & NEW FRAMES & $383.105,28$ & 16,75 & $683.924,17$ & 22,50 & 54,4 & 96,0 & 74,4 & 98,0 & 75,3 \\
\hline & INSULATED ENVELOPE & $118.803,06$ & 5,45 & $293.790,00$ & 9,80 & 38,7 & 96,0 & 61,6 & 98,0 & 64,3 \\
\hline щँ & NEW PLANTS & $410.228,61$ & 17,94 & $471.016,11$ & 15,70 & 87,1 & 96,00 & 97,00 & 98,0 & 95,4 \\
\hline & TOTAL RETROFIT & $118.803,06$ & 5,45 & $143.820,28$ & 4,80 & 82,3 & 96,00 & 97,00 & 98,0 & 90,2 \\
\hline & CURRENT SITUATIOI & $191.201,11$ & 17,64 & $302.304,17$ & 18,50 & 65,0 & 96,0 & 75,0 & 98,0 & 88,6 \\
\hline & CLADDING AND INSULATING PLASTER & $165.183,33$ & 15,24 & $270.462,50$ & 16,60 & 62,9 & 96,0 & 73,1 & 98,0 & 87,9 \\
\hline & $\begin{array}{ll}\text { ROOF INSULATION } \\
\end{array}$ & $125.351,39$ & 11,56 & $222.147,78$ & 13,60 & 58,8 & 96,0 & 67,9 & 98,0 & 87,9 \\
\hline & NEW FRAMES & $108.888,89$ & 10,04 & $184.902,50$ & 11,30 & 59,8 & 96,0 & 71,9 & 98,0 & 85,8 \\
\hline & INSULATED ENVELOPE & $41.357,78$ & 3,81 & & 5,50 & 49,1 & 96,0 & 59,2 & 98,0 & 86,4 \\
\hline & NEW PLANTS & $191.201,11$ & 17,64 & $216.715,56$ & 13,30 & 88,3 & 96,0 & 98,0 & 98,0 & 95,7 \\
\hline & TOTAL RETROFIT & $44,677,22$ & 4,12 & $52.221,39$ & 3,20 & 86,4 & 96,0 & 96,0 & 98,0 & 95,7 \\
\hline
\end{tabular}

\subsection{Guidelines for buildings in the Historic Centre}

From the table we can see how in Case Study 1, the current EPCI is calculated at approximately $14.6 \mathrm{kWh} / \mathrm{m}^{3}$ per year, on which are recorded the impact of vertical outside walls equal to $42.3 \%$, that of exterior doors and windows equal to $37.5 \%$, and of covers equal to $13.6 \%$ (buildings with $\mathrm{S} / \mathrm{V}$ aspect ratio are more advantaged). In addition, the oversizing of the plant recorded, equal to $385.4 \%$, is considerable. 
Following the works proposed, an EPCI value equivalent to $5.6 \mathrm{kWh} / \mathrm{m}^{3}$ was obtained, a percentage variation to the current state of affairs of $68.49 \%$ with a saving of $28.6337 \mathrm{kWh}$, equal to $24.62 \mathrm{TEP}$, as well as a reduction of greenhouse gas emissions of $74.58 \mathrm{tCO}_{2}$ /year.

Rescaling and making plant more efficient leads to a percentage variation to the current state of affairs of $30.1 \%$, while the optimisation of the envelope leads to a percentage variation to the current state of affairs of $40 \%$.

The envelope of the historic buildings turns out to have better performance levels than constructions from the '70-' $80 \mathrm{~s}$, in terms of transmittance, but above all of thermal inertia. To take proper courses of action, in historic buildings it is necessary to know the thermo-physical properties of the materials through thermofluximetric measurements and thermographic surveys. Once an envelope's receptivity to transformation has been defined, it is generally possible to intervene on the envelope in the following ways:

- Choice of internal thermal coating or solutions aimed at minimising the transformation of the outer envelope, often of great value or subject to particular planning restrictions;

- Particular attention to the intervention on windows and doors, where most of the thermal bridges and major problems related to excessive solar gains are to be found - regarding both light and heat - and ventilation of rooms;

- Combined intervention: new roof insulation - use of photovoltaic.

As regards plant, in the historic buildings analysed a significant oversizing of the heating system was found. Therefore, investigations will be carried out into the building's consumption (heat over the previous three years), the power of the generators and how they work, to then proceed to optimising the efficiency of production and regulation with condensing boilers and thermostatic valves. Also fundamental is evaluating the feasibility of retrofit measures for the installation of photovoltaic and solar thermal, in order to promote the use of renewable resources in the Historic Centre, in accordance with the planning restrictions imposed by the authorities.

\subsection{Guidelines for buildings in the established suburbs}

For relatively recent buildings (the ' $80 \mathrm{~s}$ ), the considerations are different. The whole system of closures is severely degraded, the level of maintenance is absolutely unsatisfactory; in particular, the system of door and window frames and shading is heading towards a state of serious degradation with significant loss for the whole performance system [13]. The intervention on the envelope is therefore more of a priority than on the plant, whose suitability can only be evaluated once the series of degradation problems that make the losses and consumption of the building unsustainable have been resolved. The starting EPCI values are, in fact, estimated at around $25 \mathrm{kWh} / \mathrm{m}^{3}$ year, with an incidence of $33 \%$ in the external window and door frames and $26.4 \%$ in the coverings. In these cases too plant being oversized by $150 \%$ to $250 \%$ is recorded.

The optimisation of the building plant system has led, in the case examined, to a post-intervention EPCI equivalent to $4.8 \mathrm{kWh} / \mathrm{m}^{3}$ per year with a percentage variation to the current state of affairs of $79.4 \%$ and a variation compared to the 
annual requirements of $483,522 \mathrm{kWh}$, equivalent to $41.58 \mathrm{TEP}$ with a reduction in the emission of greenhouse gases of $120.88 \mathrm{tCO}_{2} /$ year.

It is absolutely advantageous, therefore, to intervene on this category of buildings, with percentage variations compared to current consumption with interventions on plant alone of up to $35 \%$ and rates up to $60 \%$ with the envelope being made efficient $[14,15]$.

Having defined their receptivity to transformation, therefore, the solution for the perimeter walls will result in the choice of the thermal coating or similar solutions that lead, even with a radical transformation of the current situation, to optimising the outcome in terms of new energy efficiency with a renewal of the architectural quality of the envelope. In almost all cases, the complete replacement of windows and doors is required as well as of the renewal of the systems of screening and shading.

For the insulation of the roofs, which often consist of large flat surfaces, it will be opportune to opt for solutions with roof gardens or technological solutions which offer environmental benefits that are competitive with respect to costs, as in the case of solutions able to ensure an increased capacity to reflect solar irradiation, as in the case of cool roofs, that can deliver high solar reflectance (the ability to reflect the visible, infrared and ultraviolet wavelengths of the sun, reducing heat transfer to the building) and high thermal emittance (the ability to radiate absorbed or non-reflected solar energy). The benefits associated with cool roofs include reduced cooling energy load, reduced air pollution and greenhouse gas emission, and improved human health and comfort. Cool roofs may extend the roof service life and help in mitigating the urban heat island effect.

Table 3: $\quad$ Summery of overall results and saving conclusions.

\begin{tabular}{|c|c|c|c|c|}
\hline & Case 1: & Case 2 & Case 3 & Case 4 \\
\hline $\begin{array}{c}\text { EPCI post intervention: } \\
{\left[\mathrm{kWh} / \mathbf{m}^{3} \text { year] }\right.}\end{array}$ & 5,60 & 2,70 & 4,80 & 3,20 \\
\hline $\begin{array}{c}\text { Percent change } \\
\text { compared to present }\end{array}$ & $-79,40 \%$ & $-79,40 \%$ & $-79,40 \%$ & $-\mathbf{7 4 , 1 4 \%}$ \\
\hline $\begin{array}{c}\text { Savings per year }[\mathrm{kWh}] \\
\text { Savings per year [TEP] }\end{array}$ & $\mathbf{2 8 6 3 3 7}$ & $\mathbf{2 9 0 7 9}$ & $\mathbf{4 8 3 5 2 2}$ & $\mathbf{2 4 9 6 0 0}$ \\
\hline Savings per year [tCO $]$ & $\mathbf{7 4 , 5 8}$ & $\mathbf{6 5 , 1 8}$ & $\mathbf{1 2 0 , 8 8}$ & $\mathbf{6 2 , 4}$ \\
\hline Change with retrofit plants & $\mathbf{3 0 , 1 0 \%}$ & $\mathbf{2 8 , 7 0 \%}$ & $\mathbf{3 5 \%}$ & $\mathbf{2 8 \%}$ \\
\hline Change with retrofit envelopes & $\mathbf{4 0 \%}$ & $\mathbf{5 3 \%}$ & $\mathbf{6 0} \%$ & $\mathbf{5 8 \%}$ \\
\hline
\end{tabular}

The integrated evaluation of the choices of technological solutions for retrofitting to be employed can thus contribute to improving both the indoor microclimate of buildings as well as the outdoor, bringing a widespread benefit that can be shared with the urban context in which the intervention takes place. 
Rendering the envelope efficient will allow the recalibration of the intervention on the plant, with significant savings on peak power and, consequently, a decrease of the power needed to meet primary energy needs and costs. The use of photovoltaic and solar thermal can justify other interventions and, by studying their integration, contribute to the overall quality of the redevelopment $[16,17]$.

Finally, we can define the goal post-operam for the entire building stock, after the application of the guidelines.

For any school, historical or not, the goal is an energy requirement in the range of $3-6 \mathrm{kWh} / \mathrm{m}^{3}$ year.

\section{Conclusions}

The work carried out is a comparative experimental study on several cases of intervention. The results obtained confirm the initial hypothesis, giving the samples used a certain statistical significance, in view of a global approach to the issues of renovating the existing public housing stock.

The works proposed are shown to be suitable for a considerable number of buildings and, it follows, the guidelines above are easily applied.

The scientific validity of the results, furthermore, allows the identification of the ranges of costs and impact of any intervention on the initial energy consumption for a first rough guide aimed at speedily addressing the problems of buildings and their possibility of being resolved.

\section{References}

[1] World Energy Outlook, International Energy Agency (IEA) Web Site, www.iea.org

[2] L. De Santoli, Le comunità dell'energia, Quodlibet, 2011, ISBN 9788874624034.

[3] AA.VV. Edilizia scolastica ecocompatibile. Il Progetto Sostenibile, 17-18, Edicom, 2008.

[4] Beusker, E., Stoy C., Pollalis, S.N., Estimation model and benchmarks for heating energy consumption of schools and sport facilities in Germany, Building and Environment, Volume 49, March 2012, Pages 324-335, ISSN 0360-1323.

[5] Decreto Ministeriale 18 dicembre 1975, Norme tecniche aggiornate relative all'edilizia scolastica, ivi compresi gli indici di funzionalità didattica, edilizia ed urbanistica, da osservarsi nella esecuzione di opere di edilizia scolastica.

[6] Clemente C., Sostenibilità, sicurezza ed efficienza energetica nel recupero edilizio. Strategie per la riqualificazione integrata del patrimonio scolastico esistente nell'area metropolitana romana in PONTE, vol. 3 March 2012, pp. 23-41 ISSN:1129-3918.

[7] Pepe, D., Scuole Ecocompatibili: dal nido per l'infanzia all'Istituto Superiore, Dei, 2009. 
[8] Antonini E., Boeri A., Progettare scuole sostenibili. Criteri e analisi delle soluzioni progettuali Monfalcone, Edicom 2011, ISBN 978-88-96386-15-6.

[9] Tedesco, T., Riqualificazione energetico ambientale del costruito. Edifici scolastici, Firenze, Alinea, 2010, ISBN 978-88-605-5562-5.

[10] Boarin, P., Edilizia scolastica. Riqualificazione energetica e ambientale. Metodologie operative, requisiti, strategie ed esempi per gli interventi sul patrimonio esistente, Monfalcone, Edicom 2010, ISBN 978-88-96386-02-6.

[11] de Santoli, L., Fraticelli F., Fornari, F., Planning the integration of new technologies for sustainability: case study of a school building's restoration project in Rome. in ECO-ARCHITECTURE III, Harmonization between Architecture and Nature WIT Press, 2010, pages 423-434, ISBN 9781845644307.

[12] De Santoli, L., La gestione energetica degli edifici, Palermo Flaccovio, 2010, ISBN 9788857900162 .

[13] Clemente C. Rules, language and energy, In Housing for Europe. Strategies for Quality in Urban Space, Excellence in Design, Performance in Building, ed. Clemente, C., De Matteis, F., ROMA, DEI, pp. 79-100, 2010, ISBN 9788849625110.

[14] Dascalaki, E.G., Sermpetzoglou V.G., Energy performance and indoor environmental quality in Hellenic schools, Energy and Buildings, Volume 43, Issues 2-3, February-March 2011, Pages 718-727, ISSN 0378-7788.

[15] Gaitani, N., Lehmann, C., Santamouris, M., Mihalakakou G., Patargias,P., Using principal component and cluster analysis in the heating evaluation of the school building sector, Applied Energy, Volume 87, Issue 6, June 2010, Pages 2079-2086, ISSN 0306-2619.

[16] Dimoudi, P., Kostarela, Energy monitoring and conservation potential in school buildings in the $\mathrm{C}^{\prime}$ climatic zone of Greece, Renewable Energy, Volume 34, Issue 1, January 2009, Pages 289-296, ISSN 0960-1481.

[17] Jenkins, D.P., Peacock A. D., Banfill, P.F.G., Will future low-carbon schools in the UK have an overheating problem?, Building and Environment, Volume 44, Issue 3, March 2009, Pages 490-501, ISSN 03601323. 